\title{
Genetically modified soybean expressing insecticidal protein (CrylAc): Management risk and perspectives
}

\author{
Silvia Martins-Salles ${ }^{\mathrm{a} \star}$, Vilmar Machado ${ }^{\mathrm{b}}$, Laura Massochin-Pinto ${ }^{\mathrm{c}}$, and Lidia M. Fiuza ${ }^{\mathrm{d}}$ \\ ${ }^{a}$ PPG Biology, Universidade do Vale do Rio dos Sinos (UNISINOS), Avenida Unisinos, 950,

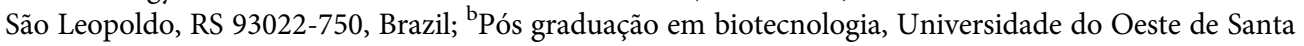 \\ Catarina-UNOESC, R. Antônio Pinto, 21-Alvorada, Videira, SC 89560-000, Brazil; ' Institute of \\ Technology in Food for Health-itt-Nutrifor, Universidade do Vale do Rio dos Sinos, Av. Unisinos, \\ 950, Cristo Rei, São Leopoldo, RS CEP 93.022-000, Brazil; ' ${ }^{\mathrm{L}}$ Laboratory of Microbiology and Toxicology; \\ EEA-Instituto Rio Grandense do Arroz, Avenida José Bonifácio de Cavalho Bernardes, 1494, \\ Cachoeirinha, RS CEP 94930-030, Brazil \\ *silviamsalles@hotmail.com
}

\section{OPEN ACCESS}

\section{Citation: Martins-Salles S, Machado V, Massochin-Pinto L, and Fiuza LM. 2017. Genetically modified soybean expressing insecticidal protein (Cry|Ac): Management risk and perspectives. FACETS 2: 496-5I2. doi: 10.1 | 39/facets-20 |7-0006 \\ Editor: Vance L. Trudeau}

Received: January 28, 2017

Accepted: May II, 2017

Published: June 15, 2017

Copyright: (C) 2017 Martins-Salles et al. This work is licensed under a Creative Commons Attribution 4.0 International License (CC BY 4.0), which permits unrestricted use, distribution, and reproduction in any medium, provided the original author(s) and source are credited.

Published by: Canadian Science Publishing

\begin{abstract}
A $B t$ soybean has been recently developed, thus, efficiently regulating the populations of major lepidopteran pests. However, in other cases, these benefits have been reduced or lost because of the rapid evolution of pest resistance to the $B t$ toxins in transgenic crops. When pest populations are exposed to $B t$ crops and to refuges (non- $B t$ plants), the evolution of resistance is governed by the fitness of resistant individuals relative to susceptible individuals for both the presence and absence of $B t$ toxins. One major ecological concern regarding the biosafety of $B t$ crops on the environment is their potential effects on non-target organisms, especially predators and parasitoids that play an important role in pest control. This information is important for supporting insect resistance management (IRM) programs and for improving agricultural practices in a crop production system with $B t$ plants. Before the use of Bt plants for insect pest control in Brazil is adopted, IRM programs should be established to ensure the sustainability of this technology for integrated pest management (IPM). This review presents data on $B t$ soybean and lepidopteran pests as well as on the importance of natural enemies as a form of biological control, and applications for IPM and IRM.
\end{abstract}

Key words: $B t$ soybean, lepidopteran pests, natural enemies, integrated pest management, insect resistance management

\section{Introduction}

Genetically modified (GM) plants resistant to insects represent a new insect pest control method for integrated pest management (IPM) programs in various agroecosystems. These plants are characterized by expressing genes of the entomopathogenic bacterium Bacillus thuringiensis Berliner (Bt) that encode the expression of proteins with insecticidal effects. There are many benefits of using $B t$ plants in agriculture, including a more efficient control of insect pests, reducing the use of insecticides, and facilitating and maintaining populations of natural enemies in the farming areas (Roush and Mckenzie 1987). The use of $B t$ plants facilitates integration with biological control in IPM programs and enables more sustainable agricultural practices (Roush and Mckenzie 1987). 
In 2015, Brazil ranked second only to the USA in the world for biotech crop hectarage, with 44.2 million ha (up from 42.2 million in 2014); the increase in 2015 was 2 million ha, equivalent to a growth rate of $5 \%$. Brazil commercially planted a soybean stacked with insect resistance and herbicide tolerance on 11.9 million ha for a third year, increasing from 2.3 million ha in 2013 to 5.2 million ha in 2014 (a fivefold increase) (James 2015).

As the Cry proteins expressed in the commercialized $B t$ crops are highly selective and have a narrow spectrum of activity, they can form an important component of IPM (Naranjo 2011). These protoxins kill lepidopteran pests because they specifically interact with receptors found in the insect gut and induce the formation of pores in the apical membrane of the cells, destroying the intestinal tissue, allowing bacterial septicemia in the hemocoel, and resulting in larval death (Raymond et al. 2010; Gómez et al. 2014). The protoxins are activated by digestive enzymes in the midgut and bind to specific receptors in the microvilli of the apical membranes of the columnar cells of the lepidopteran's gut (Höfte and Whiteley 1989; Soberón et al. 2016; Jurat-Fuentes and Crickmore 2017). The binding of Cry toxins to the apical microvillus of the membrane vesicles of the insect determines the specificity of the Cry toxins (Bravo et al. 2007). Different proteins have been identified as receptors for $B t$ in Lepidoptera and can be highlighted within Lepidoptera, including aminopeptidases (de Maagd et al. 2001; Onofre et al. 2017), "cadherin-like protein" (Gahan et al. 2001; Xiao et al. 2017), and alkaline phosphatase (Jurat-Fuentes and Adang 2004; Yuan et al. 2017). In addition to the cry genes, some $B t$ plants such as corn and cotton express vegetative insecticidal proteins from $B t$, which proved effective in the control of some economically important insect pests.

The $B t$ soybean MON $87701 \times$ MON 89788 efficiently targets a range of species, including Anticarsia gemmatalis (velvetbean caterpillar) Hübner (Lepidoptera: Erebidae) and Chrysodeixis includens (soybean looper) Walker (Lepidoptera: Noctuidae) (Bernardi et al. 2012), but it is not efficient against Spodoptera spp. (armyworms) (Bernardi et al. 2014b).

Some studies have already reported that the adoption of $B t$ crops leads to a reduction in insecticide use (Hutchison et al. 2010; Kouser and Qaim 2011; Lu et al. 2012), possibly favoring certain nontarget pest outbreaks (Zhao et al. 2011). Therefore, it is important to understand the direct and indirect impacts of $B t$ plants on both non-target pest species and their natural enemies. The maintenance of natural enemies is of paramount importance for preventing phytophagous insects from reaching population levels capable of causing economic damage (Berti and Ciociola 2002). Despite being important, there are few studies of the interactions between $B t$ plants and parasitoids of insect pests (Tian et al. 2013; Liu et al. 2014).

Before the use of $B t$ plants for insect pest control in Brazil is adopted, insect resistance management (IRM) programs should be established to ensure the sustainability of this technology for IPM. There is still a need for IRM strategies to be implemented effectively, and mitigation strategies must be designed for cases in which there is an increased frequency of resistant alleles in the populations of the target pest in $B t$ plants. This review presents data on Bt soybean and lepidopteran pests as well as on the importance of natural enemies as a form of biological control, and applications for IPM and IRM.

\section{Bt soybean}

Early efforts to obtain $B t$ soybean cultivars showed to be promising alternatives to control defoliating caterpillars in soybeans. The first report of the successful introgression and expression of a native crylAb Bt gene in soybeans was published in 1994 (Parrott et al. 1994), and several more studies on the subject have since been published. 
Stewart et al. (1996) produced a transgenic soybean plant with synthetic Bt cryIAc (tic 107) and described the tissue culture and transformation procedures and the molecular and biotic characteristics of the $B t$ soybean that was produced. Walker et al. (2000) demonstrated a transgenic lineage of the soybean 'Jack', Glycine max (L.) Merrill, expressing a synthetic crylAc gene from B. thuringiensis variety kurstaki (Jack-Bt), which was evaluated for resistance to four lepidopteran pests in the field: Helicoverpa zea (corn earworm) Boddie, A. gemmatalis (soybeans caterpillar) Hubner, C. includens (soybean looper) Walker, and Elasmopalpus lignosellus (lesser cornstalk borer) Zeller, and data from these experiments suggested that expression of this cry $1 A c$ construct in the soybean should provide adequate levels of resistance to several lepidopteran pests under field conditions. MacRae et al. (2005) developed lineages containing the event MON 87701 and expressing the synthetic protein TIC 107, which is nearly identical to the native Cryl Ac protein. Homrich et al. (2008) evaluated the agronomic performance and chromosomal stability of transgenic homozygous progenies of the soybean [G. $\max (\mathrm{L}$.) Merrill] and confirmed the resistance of these plants to A. gemmatalis.

$B t$ soybean has recently been developed by combining the transformation events MON 87701 (expressing Cry1Ac protein) and MON 89788 (glyphosate tolerance). This soybean cultivar is characterized by having the $c r y 1 A c B t$ gene encoding the CrylAc protein and the protein 5-enolpyruvylshikimate-3-phosphate synthase (EPSPS) from Agrobacterium spp. that confers tolerance to the herbicide glyphosate. The cry $1 A c$ gene is an exogenous gene from the bacterium B. thuringiensis kurstaki HD73, which confers to the plant resistance to major soybean caterpillar pests. The soybean cultivar MON 87701-2 was produced by transfering the cry $1 A c$ gene using a gene promoter rbcS4 control of the species Arabidopsis thaliana. This promoter expresses the characteristics of the gene of interest at high levels in green tissue (Cui et al. 2015). The protein sequence is $99 \%$ identical to the Cry1Ac protein from B. thuringiensis kurstaki. The Cry1 Ac protein is expressed in leaves, pollen/anthers, seeds, and pods, but not roots. The high-dose expression ( 25 times the amount required to kill $99 \%$ of a susceptible population) and concentration in the leaves can reach approximately $450 \mu \mathrm{g} / \mathrm{g}$ of the dry weight (MacRae et al. 2005).

This product was commercially released in Brazil in 2013/2014. Based on the experiences with $B t$ maize and cotton, $B t$ soybean technology is expected to control major Lepidoptera pests. Considering the ease of $B t$ soybean cultivation in addition to the increasing problems of caterpillars faced by Brazilian farmers, it is conceivable that this new technology will be widely adopted (Bernardi et al. 2012).

\section{Lepidopteran pests}

$B t$ soybean offers efficient population regulation of major lepidopteran agricultural pests such as A. gemmatalis (velvetbean caterpillar) and C. includens (soybean looper), and secondary target pests such as Heliothis virescens (tobacco budworm) Fabricius, Crocidosema aporema (bean shoot moth) Walsingham, and Rachiplusia nu (sunflower looper) Guenée (Bernardi 2012).

Caterpillars of the genus Spodoptera have been causing damage to soybean fields in Brazil in recent years (Bueno et al. 2011). Within the Spodoptera complex, S. eridania (southern armyworm) Stoll, S. cosmioides (black armyworm) Walker, and S. frugiperda (fall armyworm) J.E. Smith are prominent in causing damage. These species have attacked soybeans in central and southern Brazil (HoffmannCampo et al. 2000; dos Santos et al. 2005). The high potential for the defoliation of soybean plants (Bueno et al. 2011) and damage to flowers and pods (Hoffmann-Campo et al. 2000) by Spodoptera species requires the adoption of control tactics to prevent the loss of grain yield, but there are no data available in the literature demonstrating the impact of the protein CrylAc on the life history parameters of Spodoptera species. 
This information is important due to the threat of pests evolving resistanceto $B t$ crops (Bernardi et al. 2014b). According to Bernardi et al. (2014b), S. cosmioides, S. eridania, and S. frugiperda exhibited low to no susceptibility to MON $87701 \times$ MON 89788 soybean containing the protein Cry1 Ac. These Spodoptera species showed higher tolerance to the CrylAc protein than some other Lepidoptera species, such as C. includens, H. virescens, and H. zea (Luttrell et al. 1999).

Yu et al. (2013) showed that the Bt transgenic soybean exhibited high efficacy against Helicoverpa armigera (cotton bollworm) throughout the growing season, whereas it caused low toxicity to Spodoptera litura (tobacco cutworm), especially in the growth stages during and after anthesis. No toxicity of the Bt soybeans to Spodoptera exígua (beet armyworm) and Agrotis ypsilon (black cutworm) larvae was observed. Therefore, planting of Cry1 Ac-expressing soybeans will not effectively manage all key lepidopteran soybean pests in China (Bernardi et al. 2014a).

The low toxicity of Cry1Ac to Spodoptera species can be related to the high genetic variability among populations and the natural tolerance of insects to different $B t$ proteins. This was demonstrated for native populations of $S$. frugiperda in Mexico, Brazil, and Colombia, which showed differences in susceptibility to $B t$ strains due to high genetic variability among populations; a fact that results in groups lacking receptors for certain $B t$ proteins and, thus, are insensitive to insecticidal proteins (Monnerat et al. 2006). Aranda et al. (1996) demonstrated in trials with S. frugiperda that insufficient and (or) a weak link of the insecticidal protein in the midgut binding sites can also affect the susceptibility to Cryl Ac, which can also be related to the inactivation of the insecticidal protein by proteases (Rahman et al. 2012).

\section{Natural enemies}

Globally, insecticides are the most widely used control method for reducing damage caused by insect pests, but they have often been overused (Bueno et al. 2011). Subsequently, as an alternative to pesticide use, there has been an increase in the use of biological controls in IPM programs, both through the release of a large number of natural enemies (applied biological control) and through the use of cultural practices that preserve extant populations of natural enemies in the crop (Van Lenteren and Bueno 2003). Studies have revealed that parasitoids of the order Hymenoptera can promote the natural control of pests, especially Lepidoptera and Hemiptera (Martins et al. 2004).

The consequences of the effects of $B t$ plants on parasitoids have received attention, and studies have revealed both positive and negative impacts (Baur and Boethel 2003; Sanders et al. 2007; Dhillon and Sharma 2010). When negative effects on natural enemies have been observed with Bt proteins, they appear to be due to the poor quality of the host and not the Cry protein (Romeis et al. 2013).

The safety of several $B t$ proteins has been verified in tritrophic studies conducted with herbivores resistant or nonsusceptible to $B t$ that avoided the problems of prey quality in some other previous studies (Romeis et al. 2013). The practice of allowing Bt-resistant hosts to ingest $B t$ proteins and then feeding the hosts to natural enemies (both predators and parasitoids) has shown no effects on the natural enemies (Chen et al. 2008; Tian et al. 2012). However, some reports continue to suggest that natural enemies may be harmed by Bt proteins (Lövei et al. 2009), but these reports have been challenged (Shelton et al. 2009).

Despite being important, few studies of the interactions between $B t$ plants and the parasitoids of insect pests have been performed (Tian et al. 2013; Liu et al. 2014). Silva et al. (2014) suggested that there was no direct effect of $B t$ soybean (Cry1Ac) on the biological traits of Euchistos heros or its egg parasitoid Telenomus podisi. According to Bortolloto et al. (2014), it is important to emphasize that based on the mode of action of the Bt protein (gut-active), it is unlikely that the CrylAc, found 
in the $B t$ soybean, would be transferred from S. eridania larvae to adults to eggs. Therefore, Telenomus remus exposure to CrylAc would be zero or very low (close to zero) in this case, and direct effects are excluded. Any possible effect would be indirectly associated with the Bt protein insertion.

De Jesus et al. (2014) observed that the predation of nymphs and adults, and the effects on the life cycle of the predator Podisus nigrispinus were higher on S. frugiperda larvae fed with NuOpal (Cry1 Ac); however, the total viability of $P$. nigrispinus was lower when predating on $S$. frugiperda fed with NuOpal (transgenic cultivar). Spodoptera frugiperda acquires toxins from transgenic cotton, which can affect its natural predator P. nigrispinus. A study by Carvalho et al. (2012) showed that the integrated management of Plutella xylostella is feasible by using the HD1 strain of $B$. thuringiensis and the predator $P$. nigrispinus because the predator showed no preference for infected or healthy $P$. xylostella larvae and the strain B. thuringiensis HD1 did not affect the biological characteristics of $P$. nigrispinus when fed with infected larvae and water or healthy larvae and a $B$. thuringiensis suspension.

In a study of interactions among transgenic cotton (Cry1 Ac), H. armigera, and Campoletis chlorideae, Sharma et al. (2007) observed that there was a slight reduction in adult weight and fecundity and a prolongation of the larval period, both before and after parasitization, when the parasitoid was raised on $H$. armigera larvae fed on the leaves of transgenic cotton. Survival and development of $C$. chlorideae was also poor when $H$. armigera larvae were fed on the leaves of transgenic cotton. The adverse effects of transgenic cotton on the survival and development of C. chlorideae were largely due to early mortality, and also possibly the poor nutritional quality of the H. armigera larvae due to toxic effects of the transgenic cotton.

Parasitoids are very sensitive to changes in their hosts after the ingestion of toxins, as they usually complete their development in a single host. When susceptible hosts are treated with $B t$ toxins, the possibility of affecting the parasitoids is greater than it affecting the predators, which are often generic and feed on different prey (Salama et al. 1983). Godfray (1994) suggested that the host quality may affect parasitoid size, development, and survival. If the host is not able to survive, the parasitoid will not complete its development (Godfray 1994).

\section{Management of resistance}

Croft and Van de Bann (1988) defined resistance as the development of an inherited ability of an organism to tolerate doses of a toxicant that would be lethal to the majority of individuals of the species. In this context, the evaluation of the risk of resistance of target and non-target soybean pests MON $87701 \times$ MON 89788 is of fundamental importance to the establishment of IRM management strategies. Establishing IRM strategies to prevent or delay the evolution of insect resistance to GM soybeans is one of the main challenges for the sustainability of this new technology for the IPM of soybean crops in Brazil.

An important step in the management strategy of IRM practices includes the development of appropriate techniques for bioassays to assess the response of target pest populations to the $B t$ protein by obtaining lineages of basic plant susceptibility, from which it is possible to identify the diagnostic doses to be used in monitoring the resistance, allowing a discrimination between susceptible and resistant phenotypes, and the identification of potential changes in the susceptibility of the population in response to the selection pressure exerted by the Bt culture (Fischhoff 1996). Among the various IRM strategies that have been proposed, one that is widely used is the high-dose expression of the insecticidal protein in plant tissues and in planting and maintaining refuge areas with non-Bt plants (Fig. 1) (Alstad and Andow 1995; Gould 1998; Caprio et al. 2000; Huang et al. 2011). These strategies are based on two important observations: resistance is a recessive trait, and crosses between resistant and non-resistant individuals occur at random (Fig. 2) (Machado and Fiuza 2011). 


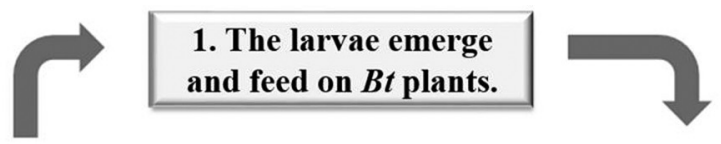

\section{The offspring reproduce and lay their eggs on the $B t$ plants and the cycle restarts.} in Brazil (CTNBio 2010).

\section{Most larvae die after ingestion of $B t$ plants.}

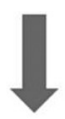

\section{The rare resistant}

individuals (rr) cross with nonresistant (RR) producing offspring (Rr).

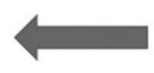

\section{Few resistant} individuals (rr) survive.

Fig. 1. Basic aspects of resistance management with the high dose and structured refuge strategy.

Refuge areas then supply susceptible individuals to minimize non-random mating among the rare resistant homozygotes that survive on $B t$ plants, ensuring that the next generation consists of either susceptible or heterozygous resistant individuals. These insects are all phenotypically susceptible to the high-dose plant (Andow 2008; Tabashnik et al. 2009).

For the MON $87701 \times$ MON 89788 soybean, the recommendation of a refuge area (with non- $B t$ soybean) of at least $20 \%$ of the area planted with MON $87701 \times$ MON 89788 soybean was approved

The wide use of MON $87701 \times$ MON 89788 by Brazilian producers increases concern of the evolution of resistance. The main risks for the maintenance of this lineage over time are the failure to observe the three main foundations of the management strategy used, namely high doses, low frequency of the gene for resistance, and maintenance of the areas of refuge, according to the recommendations (Huang et al. 2011; Tabashnik et al. 2013; Omoto et al. 2016). A study by Dourado et al. (2016) evaluating the efficiency of this lineage in the control of $H$. armigera indicated that the first two conditions are present in Brazil. The great concern of the authors the maintenance of the areas of refuge, as these are not obligatory in Brazil; areas for cultivation of $B t$ soybean may be an additional challenge for the management of resistance in the country, because temperatures are higher and the cultivation time is longer than in temperate areas. The concern with the effects of other factors is not exclusive to $B t$ soybeans, but to all $B t$ plants. It is extremely important to adopt adequate management procedures in each region, because it is necessary to consider the differences in geography, climate, size of cultivated area, number of transgenic species cultivated, biology of insect pests, and spatial and temporal genetic variability of the target species (Omoto et al. 2016; Ives et al. 2017).

The need for transgenic plants expressing different genes is reinforced by the evolution of pest lineages resistant to $B t$ plants in the field (Table 1). Field-evolved resistances in different insect pests in other regions such as the resistance of Pectinophora gossypiella to Cryl Ac in Bt cotton in India (Dhurua and Gujar 2011), the resistance of H. zea to CrylAc in Bt cotton in the USA (Tabashnik et al. 2013), and the resistance of Diabrotica virgifera to Cry3Bb in Bt corn in the USA (Gassmann et al. 2011) have also been reported. In addition, the resistance of $S$. frugiperda to Cry1F in maize 


\section{High dose-refuge strategy}

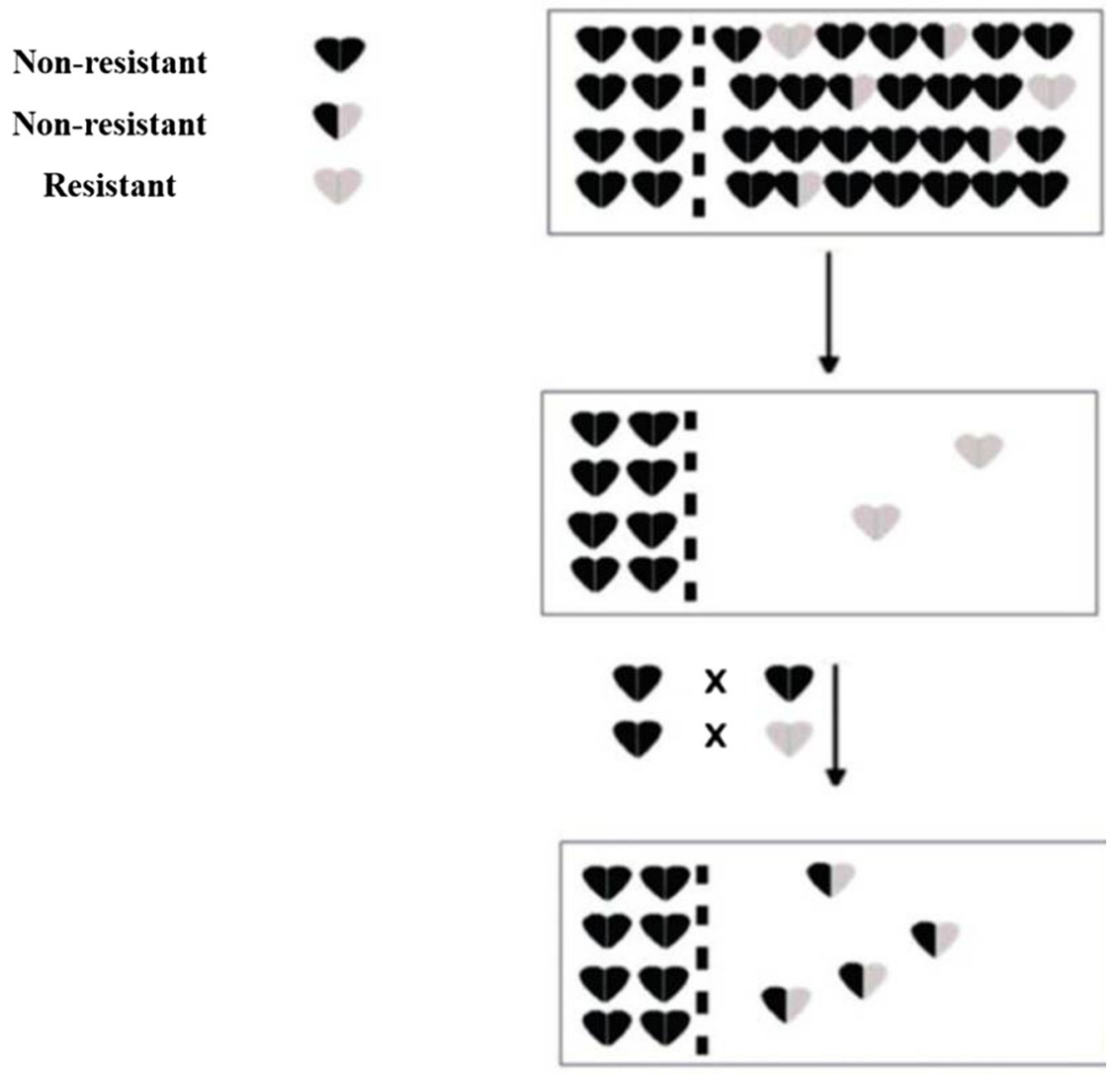

Fig. 2. The high dose and structured refuge strategy. The parameters for this strategy are as follows: the gene for resistance occurs at a low frequency in insect populations, the amounts of $B t$ toxin produced by plants are high enough to eliminate non-resistant (homozygous recessive) insects, and resistant heterozygotes and resistant individuals (dominant homozygotes) born in areas with $B t$ plants randomly interbreed with the non-resistant individuals born in the refuge areas. The purpose of the refuges is to keep individuals susceptible to $B t$ toxin (i.e., those that do not have genes for resistance) in the population. Their contribution is the production of adult insects susceptible to $B t$ toxin for breeding with resistant homozygous insects, thus, "diluting" the resistance in the population. Dispersion out of the refuge areas is necessary for breeding to occur.

Table 1. Pest species with field resistance to $B t$ plants.

\begin{tabular}{lllll} 
Pest & $\begin{array}{c}\text { Resistance detected } \\
\text { (year) }\end{array}$ & Crop & Country & Gene \\
\hline Helicoverpa zea & 2002 & Cotton & USA & cry1Ac \\
Busseola fusca & 2004 & Maize & South Africa & cry1F \\
\hline Spodoptera frugiperda & 2007 & Maize & Puerto Rico/Brazil & cry1Ac \\
\hline Pectinophora gossypiella & 2009 & Cotton & India & cry3Bb1 \\
\hline Dibarotica virgifera virgifera & 2010 & Maize & USA & cry1Ab \\
\hline
\end{tabular}


(Storer et al. 2010; Farias et al. 2014) and the resistance of P. gossypiella (Saunders) to Cryl Ac in cotton (Dhurua and Gujar 2011) have been reported.

For many researchers, second generation transgenic plants, i.e., those that express two or more $B t$ toxins, are a more effective option for pest control and also to increase the longevity of transgenic plants (Carrière et al. 2015; Sheikh et al. 2017). In Brazil, for example, studies demonstrated a high efficiency of the $B t$ soybean strain DAS-81419-2 (expressing two proteins) in the reduction of damage caused by A. gemmatalis, C. includens, $H$. virescens, and S. cosmioides during the vegetative and reproductive stages (Marques et al. 2016). Recent studies have suggested the use of RNA interference as a promising alternative or complementary strategy for pest control and management (Asokan et al. 2014; Kim et al. 2015; Fishilevich et al. 2016; Yu et al. 2016; Ni et al. 2017).

\section{Final considerations}

In Brazil, as in other countries that grow Bt soybeans, the main strategy for pest management is high doses and maintenance of refuges. The main objective is to delay the evolution of resistance to $B t$ toxins in the target pests. Studies indicate that this strategy is efficient to ensure the longevity of Bt plants (Shelton et al. 2002; Wenes et al. 2006; Yang et al. 2015; Garcia et al. 2016).

One of the main problems in the cultivation of $B t$ soybeans in Brazil is the emergence of secondary pests. Several studies have reported significant losses in production by the action of these species (Ferreira et al. 2015; Pomari-Fernandes et al. 2015). The technological solution to this problem is the production of transgenic plants expressing a higher number of $B t$ toxins, as indicated in the results obtained by Marques et al. (2017), which show the high efficiency of a soybean variety containing two $B t$ toxins in the control of primary and secondary pests. The recommended strategies for controlling problematic pests are the cultivation of plants expressing genes for two or three $B t$ toxins, the expansion of refuge areas, and the use of other management tactics (Carrière et al. 2016a, 2016b; Ni et al. 2017).

The emergence of secondary pests is a possibility that can not be discounted, especially for plants such as soybeans that are targets of different insect species (Zeilinger et al. 2016; Marques et al. 2017). The relevant question here is as follows: how are we going to address this possibility? To use only the technological solution of increasing the number of toxins expressed by Bt plants, or seek ecological solutions of greater complexity? A more complex solution requires a more accurate assessment of the effective contribution of natural enemies in reducing the impact of primary and secondary pests as well as changes in the methods of large-scale plant cultivation. In addition, it should take into account other information, such as geographical aspects of cultivated areas, target pest biology, and genetic variability (Omoto et al. 2016; Ives et al. 2017).

Several studies have indicated the potential of natural enemies to help in the fight against soybean pests (Liu et al. 2014; Macfadyen et al. 2015; Zalucki et al. 2015), but the introduction of these species is difficult in homogeneous crops, as they occur over large areas of cultivation. Perhaps in the near future it will be necessary to implement cultivation processes in large areas that will increase plant diversity and, thus, favor the presence of the natural enemies of the main pests. González et al. (2017) found a greater diversity of the natural enemies of soybean pests in cultivated areas with a greater diversity of vegetal species nearby. In these areas there was a greater contribution of the natural enemies to the control of stink bugs (Hemiptera: Pentatomidae). The importance of plant diversity for the development and maintenance of the diversity of natural enemies in cultivated areas has also been highlighted by Harterreiten-Souza et al. (2014), Venugopal et al. (2014), Mitchell et al. (2014a, 2014b), Cohen and Crowder (2017), and Maisonhaute et al. (2017). In Brazil, there are studies indicating the possibility of using natural enemies in the fight against soybean pests (Reichert et al. 2014, 2016; Paz-Neto et al. 2015; Cividanes et al. 2017). 
The history of pest control shows that the evolution of resistance to the control agents that are developed is only a matter of time. Over the course of the relationship of human beings with the pests of cultivated plants, we have developed a set of strategies to minimize losses in production and have become aware that our relationship with pests is continuous in space and time. These strategies minimized the losses and increased the useful life of the control agents. The strategy of "high doses and structured shelter" should be considered the minimum necessary in terms of pest control and management. It is necessary, however, to extend the set of procedures used. In this sense, the development of management strategies that are more complex and that really favor the increase of the diversity of agroecosystems is fundamental; these strategies will enable an increase in and maintenance of the diversity of natural enemies.

\section{Acknowledgements}

We thank the Brazilian National Council for Scientific and Technological Development (CNPq) for financial support and the Brazilian Coordination of Improvement of High-level Education (Capes) for granting a doctoral scholarship to the senior author.

\section{Author contributions}

Conceived and designed the study: SM-S, LMF. Performed the experiments/collected the data: SM-S, LM-P. Analyzed and interpreted the data: SM-S, LM-P. Contributed resources: SM-S, VM, LM-P. Drafted or revised the manuscript: SM-S, VM, LM-P, LMF.

\section{Competing interests}

The authors have declared that no competing interests exist.

\section{Data accessibility statement}

All relevant data are within the paper.

\section{References}

Alstad DN, and Andow DA. 1995. Managing the evolution of insect resistance to transgenic plants. Science, 268: 1894-1896. PMID:17797533. doi:10.1126/science.268.5219.1894.

Andow DA. 2008. The risk of resistance evolution in insects to transgenic insecticidal crops. Collection of Biosafety Reviews, 4: 142-199.

Aranda E, Sanchez J, Peferoen M, Güereca L, and Bravo A. 1996. Interactions of Bacillus thuringiensis crystal proteins with the midgut epithelial cells of Spodoptera frugiperda (Lepidoptera: Noctuidae). Journal of Invertebrate Pathology, 68: 203-212. PMID:8931361. doi:10.1006/jipa.1996.0087.

Asokan R, Chandra GS, Manamohan M, Kumar NKK, and Sita T. 2014. Response of various target genes to diet-delivered dsRNA mediated RNA interference in the cotton bollworm, Helicoverpa armigera. Journal of Pest Science, 87: 163-172. doi:10.1007/s10340-013-0541-7.

Baur ME, and Boethel DJ. 2003. Effect of Bt-cotton expressing Cry1A(c) on the survival and fecundity of two hymenopteran parasitoids (Braconidae, Encyrtidae) in the laboratory. Biological Control, 26: 325-332. doi:10.1016/S1049-9644(02)00160-3.

Bernardi O. 2012. Avaliação do risco de resistência de lepidópteros-praga (Lepidoptera: Noctuidae) à proteína Cry1Ac expressa em soja MON87701 × MON89788. Ph.D. thesis, Escola Superior de Agricultura Luiz de Queiroz, Piracicaba, Brazil. 117 p. 
Bernardi O, Malvestiti GS, Dourado PM, Oliveira WS, Martinelli S, Berger GU, et al. 2012. Assessment of the high-dose concept and level of control provided by MON $87701 \times$ MON 89788 soybean against Anticarsia gemmatalis and Pseudoplusia includens (Lepidoptera: Noctuidae) in Brazil. Pest Management Science, 68: 1083-1091. PMID:22407725. doi:10.1002/ps.3271.

Bernardi O, Dourado PM, Carvalho RA, Martinelli S, Berger GU, Head GP, et al. 2014a. High levels of biological activity of Cry1Ac protein expressed on MON $87701 \times$ MON 89788 soybean against Heliothis virescens (Lepidoptera: Noctuidae). Pest Management Science, 70: 588-594. PMID:23687086. doi:10.1002/ps.3581.

Bernardi O, Sorgatto RJ, Barbosa AD, Domingues FA, Dourado PM, Carvalho RA, et al. 2014b. Low susceptibility of Spodoptera cosmioides, Spodoptera eridania and Spodoptera frugiperda (Lepidoptera: Noctuidae) to genetically-modified soybean expressing Cry1Ac protein. Crop Protection, 58: 33-40. doi:10.1016/j.cropro.2014.01.001.

Berti FE, and Ciociola AI. 2002. Parasitoides ou predadores? Vantagens e desvantagens. In Controle biológico no Brasil: parasitóides e predadores. Edited by JRP Parra, PSM Botelho, BS CorrêaFerreira, and JMS Bento. Editora Manole, Barueri, Brazil. pp. 29-41.

Bortolloto OC, Silva GV, de Freitas Bueno A, Pomari AF, Martinelli S, Head GP, et al. 2014. Development and reproduction of Spodoptera eridania (Lepidoptera: Noctuidae) and its egg parasitoid Telenomus remus (Hymenoptera: Platygastridae) on the genetically modified soybean (Bt) MON $87701 \times$ MON 89788. Bulletin of Entomological Research, 104: 724-730. doi:10.1017/ S0007485314000546.

Bravo A, Gill SS, and Soberón M. 2007. Mode of action of Bacillus thuringiensis Cry and Cyt toxins and their potential for insect control. Toxicon, 49: 423-435. PMID:17198720. doi:10.1016/j. toxicon.2006.11.022.

Bueno RCOF, Bueno AF, Moscardi F, Parra JRP, and Hoffmann-Campo CB. 2011. Lepidopteran larva consumption of soybean foliage: basis for developing multiple-species economic thresholds for pest management decisions. Pest Management Science, 67: 170-174. PMID:20981726. doi:10.1002/ ps.2047.

Caprio MA, Summerford DV, and Sims SR. 2000. Evaluating transgenic plants for suitability in pest and resistance management programs. In Field manual of techniques in invertebrate pathology. Edited by LA Lacey and HK Kaya. Kluwer Academic, Dordrecht, the Netherlands. Chapter 8, pp. 805-828.

Carrière Y, Crickmore N, and Tabashnik BE. 2015. Optimizing pyramided transgenic Bt crops for sustainable pest management. Nature Biotechnology, 33(2): 161-168. PMID:25599179. doi:10.1038/ nbt.3099.

Carrière Y, Fabrick JA, and Tabashnik BE. 2016a. Advances in managing pest resistance to Bt crops: pyramids and seed mixtures. In Advances in insect control and resistance management. Edited by AR Horowitz and I Ishaaya. Springer International Publishing, Cham, Switzerland. pp. 263-286.

Carrière Y, Fabrick JA, and Tabashnik BE. 2016b. Can pyramids and seed mixtures delay resistance to Bt crops? Trends in Biotechnology, 34: 291-302. PMID:26774592. doi:10.1016/j.tibtech.2015.12.011.

Carvalho VFP, Vacari AM, Pomari AF, De Bortoli CP, Ramalho DG, and De Bortoli SA. 2012. Interaction between the predator Podisus nigrispinus (Hemiptera: Pentatomidae) and the 
entomopathogenic bacteria Bacillus thuringiensis. Environmental Entomology, 41: 1454-1461. PMID:23321092. doi:10.1603/EN12060.

Chen M, Zhao JZ, Collins HL, Earle ED, Cao J, and Shelton AM. 2008. A critical assessment of the effects of $B t$ transgenic plants on parasitoids. PLoS ONE, 3: e2284. PMID:18523682. doi:10.1371/ journal.pone.0002284.

Cividanes FJ, dos Santos-Cividanes TM, Ferraudo AS, and da Matta DH. 2017. Edge effects on carabid beetles (Coleoptera: Carabidae) between forest fragments and agricultural fields in south-east Brazil. Austral Entomology. doi:10.1111/aen.12263.

Cohen AL, and Crowder DW. 2017. The impacts of spatial and temporal complexity across landscapes on biological control: a review. Current Opinion in Insect Science, 20: 13-18. doi:10.1016/j. cois.2017.02.004.

Comissão Técnica Nacional de Biossegurança (CTNBio). 2010. Commercial release of genetically modified insect-resistant and herbicide-tolerant soy containing genetically modified events MON 87701 and MON 89788. Technical Opinion No. 2542/2010 [online]: Available from ctnbio.mcti.gov. br/documents/566529/686342/Extrato+de+Parecer+n\%C2\%BA\%202542.2010.pdf/3f5030f6-c71d4999-9504-72239fc4f9c4?version=1.0.

Croft BA, and Van De Bann HE. 1988. Ecological and genetic factors influencing evolution of pesticide resistance in tetranychid and phytoseiid mites. Experimental \& Applied Acarology, 4: 277-300. doi:10.1007/BF01196191.

Cui XY, Chen ZY, Wu L, Liu XQ, Dong YY, Wang FW, et al. 2015. rbcS SRS4 promoter from Glycine max and its expression activity in transgenic tobacco. Genetics and Molecular Research, 14: 7395-7405. PMID:26214418. doi:10.4238/2015.July.3.15.

De Jesus FG, Boiça AL Jr, Alves GCS, and Zanuncio JC. 2014. Behavior, development, and predation of Podisus nigrispinus (Hemiptera: Pentatomidae) on Spodoptera frugiperda (Lepidoptera: Noctuidae) fed transgenic and conventional cotton cultivars. Annals of the Entomological Society of America, 107(3): 601-606. doi:10.1603/AN13100.

de Maagd RA, Bravo A, and Crickmore N. 2001. How Bacillus thuringiensis has evolved specific toxins to colonize the insect world. Trends in Genetics, 17: 193-199. PMID:11275324. doi:10.1016/ S0168-9525(01)02237-5.

Dhillon KM, and Sharma CH. 2010. Chickpea-mediated effects of Bacillus thuringiensis on Helicoverpa armigera and its larval parasitoid, Campoletis chlorideae. Journal of Applied Entomology, 134: 682-693. doi:10.1111/j.1439-0418.2010.01506.x.

Dhurua S, and Gujar GT. 2011. Field-evolved resistance to Bt toxin Cry1Ac in the pink bollworm, Pectinophora gossypiella (Saunders) (Lepidoptera: Gelechiidae), from India. Pest Management Science, 67: 898-903. PMID:21438121. doi:10.1002/ps.2127.

dos Santos KB, Meneguim AM, and Neves PMOJ. 2005. Biologia de Spodoptera eridania (Cramer) (Lepidoptera: Noctuidae) em diferentes hospedeiros. Neotropical Entomology, 34: 903-910. doi:10.1590/S1519-566X2005000600005.

Dourado PM, Bacalhau FB, Amado D, Carvalho RA, Martinelli S, Head GP, et al. 2016. High susceptibility to Cry1Ac and low resistance allele frequency reduce the risk of resistance of Helicoverpa 
armigera to Bt soybean in Brazil. PLoS ONE, 11(8): e0161388. PMID:27532632. doi:10.1371/journal. pone.0161388.

Farias JR, Andow DA, Horikoshi RJ, Sorgatto RJ, Fresia P, Dos Santos AC, et al. 2014. Field-evolved resistance to Cry1F maize by Spodoptera frugiperda (Lepidoptera: Noctuidae) in Brazil. Crop Protection, 64: 150-158. doi:10.1016/j.cropro.2014.06.019.

Ferreira BGC, Freitas MML, and Moreira GC. 2015. Custo operacional efetivo de produção de soja em sistema de plantio direto. Revista iPecege, 1: 39-50. doi:10.22167/r.ipecege.2015.1.39.

Fischhoff DA. 1996. Insect-resistant crop plants. In Biotechnology and integrated pest management. Edited by GJ Persley. Cabi International, Wallingford, UK. pp. 214-227.

Fishilevich E, Vélez AM, Storer NP, Li H, Bowling AJ, Rangasamy M, et al. 2016. RNAi as a management tool for the western corn rootworm, Diabrotica virgifera virgifera. Pest Management Science, 72: 1652-1663. PMID:27218412. doi:10.1002/ps.4324.

Gahan LJ, Gould F, and Heckel DG. 2001. Identification of a gene associated with Bt resistance in Heliothis virescens. Science, 293: 857-860. PMID:11486086. doi:10.1126/science.1060949.

Garcia AG, Ferreira CP, Cônsoli FL, and Godoy WA. 2016. Predicting evolution of insect resistance to transgenic crops in within-field refuge configurations, based on larval movement. Ecological Complexity, 28: 94-103. doi:10.1016/j.ecocom.2016.07.006.

Gassmann AJ, Petzold-Maxwell JL, Keweshan RS, and Dunbar MW. 2011. Field-evolved resistance to Bt maize by western corn rootworm. PLoS ONE, 6: e22629. PMID:21829470. doi:10.1371/journal. pone.0022629.

Godfray HCJ. 1994. Parasitoids: behavioural and evolutionary ecology. Princetown University Press, Princetown, New Jersey. 473 p.

Gómez I, Sánchez J, Muñoz-Garay C, Matus V, Gill SS, Soberón M, et al. 2014. Bacillus thuringiensis Cry1A toxins are versatile proteins with multiple modes of action: two distinct pre-pores are involved in toxicity. Biochemical Journal, 459: 383-396. PMID:24456341. doi:10.1042/BJ20131408.

González E, Salvo A, and Valladares G. 2017. Arthropod communities and biological control in soybean fields: forest cover at landscape scale is more influential than forest proximity. Agriculture, Ecosystems \& Environment, 239: 359-367. doi:10.1016/j.agee.2017.02.002.

Gould F. 1998. Sustainability of transgenic insecticidal cultivars: integrating pest genetics and ecology. Annual Review of Entomology, 43: 701-726. PMID:15012402. doi:10.1146/annurev.ento.43.1.701.

Harterreiten-Souza ÉS, Togni PHB, Pires CSS, and Sujii ER. 2014. The role of integrating agroforestry and vegetable planting in structuring communities of herbivorous insects and their natural enemies in the Neotropical region. Agroforestry Systems, 88(2): 205-219. doi:10.1007/s10457-013-9666-1.

Hoffmann-Campo CB, Moscardi F, Ferreira BC, Oliveira LJ, Sosa DRG, Panizzi AR, et al. 2000. Pragas da soja no Brasil e seu manejo integrado. EMBRAPA, Dourados, Brazil. pp. 30-70.

Höfte H, and Whiteley HR. 1989. Insecticidal crystal proteins of Bacillus thuringiensis. Microbiology and Molecular Biology Reviews, 53: 242-255. PMID:2666844. 
Homrich MS, Passaglia LMP, Pereira JF, Bertagnolli PF, Pasquali G, Zaidi MA, et al. 2008. Resistance to Anticarsia gemmatalis Hübner (Lepidoptera, Noctuidae) in transgenic soybean (Glycine max (L.) Merrill Fabales, Fabaceae) cultivar IAS5 expressing a modified Cry1 Ac endotoxin. Genetics and Molecular Biology, 31: 522-531. doi:10.1590/S1415-47572008000300020.

Huang F, Andow DA, and Buschman LL. 2011. Success of the high-dose/refuge resistance management strategy after 15 years of Bt crop use in North America. Entomologia Experimentalis et Applicata, 140: 1-16. doi:10.1111/j.1570-7458.2011.01138.x.

Hutchison WD, Burkness EC, Mitchell PD, Moon RD, Leslie TW, Fleischer SJ, et al. 2010. Areawide suppression of European corn borer with $B t$ maize reaps savings to non- $B t$ maize growers. Science, 330: 222-225. PMID:20929774. doi:10.1126/science.1190242.

Ives AR, Paull C, Hulthen A, Downes S, Andow DA, Haygood R, et al. 2017. Spatio-temporal variation in landscape composition may speed resistance evolution of pests to Bt crops. PLoS ONE, 12: e0169167. PMID:28046073. doi:10.1371/journal.pone.0169167.

James C. 2015. Global status of commercialized biotech/GM crops. ISAAA Brief No. 51. ISAAA, Ithaca, New York.

Jurat-Fuentes JL, and Adang MJ. 2004. Characterization of a Cry1Ac-receptor alkaline phosphatase in susceptible and resistant Heliothis virescens larvae. European Journal of Biochemistry, 271: 31273135. PMID:15265032. doi:10.1111/j.1432-1033.2004.04238.x.

Jurat-Fuentes JL, and Crickmore N. 2017. Specificity determinants for Cry insecticidal proteins: insights from their mode of action. Journal of Invertebrate Pathology, 142: 5-10. PMID:27480404. doi:10.1016/j.jip.2016.07.018.

Kim YH, Issa MS, Cooper AMW, and Zhu KY. 2015. RNA interference: applications and advances in insect toxicology and insect pest management. Pesticide Biochemistry and Physiology, 120: 109-117. PMID:25987228. doi:10.1016/j.pestbp.2015.01.002.

Kouser S, and Qaim M. 2011. Impact of Bt cotton on pesticide poisoning in smallholder agriculture: a panel data analysis. Ecological Economics, 70: 2105-2113. doi:10.1016/j. ecolecon.2011.06.008.

Liu X, Chen M, Collins HL, Onstad DW, Roush RT, Zhang Q, et al. 2014. Natural enemies delay insect resistance to $B t$ crops. PLoS ONE, 9: e90366. PMID:24595158. doi:10.1371/journal. pone.0090366.

Lövei GL, Andow DA, and Arpaia S. 2009. Transgenic insecticidal crops and natural enemies: a detailed review of laboratory studies. Environmental Entomology, 38: 293-306. PMID:19389277. doi:10.1603/022.038.0201.

Lu Y, Wu K, Jiang Y, Guo Y, and Desneux L. 2012. Widespread adoption of Bt cotton and insecticide decrease promotes biocontrol services. Nature, 487: 362-365. PMID:22722864. doi:10.1038/ nature11153.

Luttrell RG, Wan L, and Knighten K. 1999. Variation in susceptibility of noctuid (Lepidoptera) larvae attacking cotton and soybean to purified endotoxin proteins and commercial formulations of Bacillus thuringiensis. Journal of Economic Entomology, 92: 21-32. doi:10.1093/jee/92.1.21. 
Macfadyen S, Davies AP, and Zalucki MP. 2015. Assessing the impact of arthropod natural enemies on crop pests at the field scale. Insect Science, 22: 20-34. PMID:25219624. doi:10.1111/ 1744-7917.12174.

Machado V, and Fiuza LM. 2011. Manejo da resistência: na era das plantas transgênicas. Oecologia Australis, 15: 291-302. doi:10.4257/oeco.2011.1502.07.

Macrae TC, Baur ME, Boethel DJ, Fitzpatrick BJ, Gao AG, Gamundi JC, et al. 2005. Laboratory and field evaluations of transgenic soybean exhibiting high-dose expression of a synthetic Bacillus thuringiensis cry $1 \mathrm{~A}$ gene for control of Lepidoptera. Journal of Economic Entomology, 98: 577-587. PMID:15889751. doi:10.1093/jee/98.2.577.

Maisonhaute JÉ, Labrie G, and Lucas E. 2017. Direct and indirect effects of the spatial context on the natural biocontrol of an invasive crop pest. Biological Control, 106: 64-76. doi:10.1016/j. biocontrol.2016.12.010.

Marques LH, Castro BA, Rossetto J, Silva OABN, Moscardini VF, Zobiole LHS, et al. 2016. Efficacy of soybean's event DAS-81419-2 expressing Cry1F and Cry1 Ac to manage key tropical lepidopteran pests under field conditions in Brazil. Journal of Economic Entomology, 109: 1922-1928. PMID:27401112. doi:10.1093/jee/tow153.

Marques LH, Santos AC, Castro BA, Moscardini VF, Rossetto J, Silva OAN, et al. 2017. Field evaluation of soybean transgenic event DAS-81419-2 expressing Cry1F and Cry1Ac proteins for the control of secondary lepidopteran pests in Brazil. Crop Protection, 96: 109-115. doi:10.1016/j. cropro.2017.02.014.

Martins JF, Grutzmacher AD, and Cunha U. 2004. Descrição e manejo integrado de insetos-praga em arroz irrigado. In Arroz irrigado no Sul do Brasil. Edited by ASG Gomes and AMJ Magalhães. Embrapa Informação Tecnológica, Brasília, Brazil. pp. 635-675.

Mitchell MG, Bennett EM, and Gonzalez A. 2014a. Agricultural landscape structure affects arthropod diversity and arthropod-derived ecosystem services. Agriculture, Ecosystems \& Environment, 192: 144-151. doi:10.1016/j.agee.2014.04.015.

Mitchell MG, Bennett EM, and Gonzalez A. 2014b. Forest fragments modulate the provision of multiple ecosystem services. Journal of Applied Ecology, 51: 909-918. doi:10.1111/1365-2664.12241.

Monnerat R, Martins E, Queiroz P, Ordúz S, Jaramillo G, Benintende G, et al. 2006. Genetic variability of Spodoptera frugiperda Smith (Lepidoptera: Noctuidae) populations from Latin America is associated with variations in susceptibility to Bacillus thuringiensis Cry toxins. Applied and Environmental Microbiology, 72: 7029-7035. PMID:16936049. doi:10.1128/AEM.01454-06.

Naranjo SE. 2011. Impact of $B t$ transgenic cotton on integrated pest management. Journal of Agricultural and Food Chemistry, 59: 5842-5851. PMID:20942488. doi:10.1021/jf102939c.

Ni M, Ma W, Wang X, Gao M, Dai Y, Wei X, et al. 2017. Next-generation transgenic cotton: pyramiding RNAi and $B t$ counters insect resistance. Plant Biotechnology Journal, 15(3): 1-10. PMID:28199783. doi:10.1111/pbi.12709.

Omoto C, Bernardi O, Salmeron E, Sorgatto RJ, Dourado PM, Crivellari A, et al. 2016. Field-evolved resistance to Cry1 Ab maize by Spodoptera frugiperda in Brazil. Pest Management Science, 72: 17271736. PMID:26617261. doi:10.1002/ps.4201. 
Onofre J, Gaytán MO, Peña-Cardeña A, García-Gomez BI, Pacheco S, Gómez I, et al. 2017. Identification of Aminopeptidase- $\mathrm{N} 2$ as a Cry2 Ab binding protein in Manduca sexta. Peptides, 88(1): 1-6. PMID:28108197. doi:10.1016/j.peptides.2017.01.006.

Parrott WA, All JN, Adang MJ, Bailey MA, Boerma HR, and Stewart CN Jr. 1994. Recovery and evaluation of soybean plants transgenic for a Bacillus thuringiensis var. kurstaki insecticidal gene. In Vitro Cellular \& Developmental Biology_Plant, 30: 144-149. doi:10.1007/ BF02632204.

Paz-Neto AA, Ranyse BQ, and Margaría CB. 2015. Egg parasitoids of stink bugs (Hemiptera: Coreidae and Pentatomidae) on soybean and cowpea in Brazil. Florida Entomologist, 98(3): 929-932. doi:10.1653/024.098.0318.

Pomari-Fernandes A, De Freitas Bueno A, and Sosa-Gómez DR. 2015. Helicoverpa armigera: current status and future perspectives in Brazil. Current Agricultural Science and Technology, 21: 1-7. doi:10.18539/cast.v21i1.4234.

Rahman K, Abdullah MAF, Ambati S, Taylor MD, and Adang MJ. 2012. Differential protection of Cry1Fa toxin against Spodoptera frugiperda larval gut proteases by cadherin orthologs correlates with increased synergism. Applied and Environmental Microbiology, 78: 354-362. PMID:22081566. doi:10.1128/AEM.06212-11.

Raymond B, Johnston PR, Nielsen-LeRoux C, Lereclus D, and Crickmore N. 2010. Bacillus thuringiensis: an impotent pathogen? Trends in Microbiology, 18: 189-194. PMID:20338765. doi:10.1016/ j.tim.2010.02.006.

Reichert MB, Da Silva GL, Rocha MDS, Johann L, and Ferla NJ. 2014. Mite fauna (Acari) in soybean agroecosystem in the northwestern region of Rio Grande do Sul State, Brazil. Systematic and Applied Acarology, 19(2): 123-136. doi:10.11158/saa.19.2.2.

Reichert MB, Toldi M, Rode PA, Ferla JJ, and Ferla NJ. 2016. Biological performance of the predatory mite Neoseiulus idaeus (Phytoseiidae): a candidate for the control of tetranychid mites in Brazilian soybean crops. Brazilian Journal of Biology. PMID:27533728. doi:10.1590/1519-6984.14915.

Romeis J, McLean MA, and Shelton AM. 2013. When bad science makes good headlines: Bt maize and regulatory bans. Nature Biotechnology, 31: 386-387. PMID:23657387. doi:10.1038/nbt.2578.

Roush RT, and Mckenzie JA. 1987. Ecological genetics of inseticide and acaricide resistance. Annual Review of Entomology, 32: 361-380. PMID:3545056. doi:10.1146/annurev.en.32.010187. 002045.

Salama HS, Sharaby A, and Ragaei M. 1983. Chemical changes in the haemolymph of Spodoptera littoralis [Lep.: Noctuidae] as affected by Bacillus thuringiensis. Entomophaga, 28: 331-337. doi:10.1007/ BF02372185.

Sanders CJ, Pell JK, Poppy GM, Raybould A, Garcia-Alonso M, and Schuler TH. 2007. Host-plant mediated effects of transgenic maize on the insect parasitoid Campoletis sonorensis (Hymenoptera: Ichneumonidae). Biological Control, 40: 362-369. doi:10.1016/j.biocontrol.2006.12.010.

Sharma HC, Arora R, and Pampapathy G. 2007. Influence of transgenic cottons with Bacillus thuringiensis cry $1 A c$ gene on the natural enemies of Helicoverpa armigera. BioControl, 52: 469-489. doi:10.1007/s10526-006-9032-6. 
Sheikh AA, Wani MA, Bano P, Un S, Nabi TAB, Bhat MA, et al. 2017. An overview on resistance of insect pests against $B t$ crops. Journal of Entomology and Zoology Studies, 5: 941-948.

Shelton AM, Zhao J-Z, and Roush RT. 2002. Economic, ecological, food safety, and social consequences of the deployment of $B t$ transgenic plants. Annual Review of Entomology, 47: 845-881. PMID:11729093. doi:10.1146/annurev.ento.47.091201.145309.

Shelton AM, Naranjo SE, Romeis J, Hellmich RL, Wolt JD, Federici BA, et al. 2009. Setting the record straight: a rebuttal to an erroneous analysis on transgenic insecticidal crops and natural enemies. Transgenic Research, 18: 317-322. PMID:19357987. doi:10.1007/s11248-009-9260-5.

Silva GV, Pasini A, Bueno ADF, Bortolotto OC, Barbosa GC, and Cruz YKS. 2014. No impact of Bt soybean that express CrylAc protein on biological traits of Euschistus heros (Hemiptera, Pentatomidae) and its egg parasitoid Telenomus podisi (Hymenoptera, Platygastridae). Revista Brasileira de Entomologia, 58: 285-290. doi:10.1590/S0085-56262014000300010.

Soberón M, Monnerat R, and Bravo A. 2016. Mode of action of Cry toxins from Bacillus thuringiensis and resistance mechanisms. In Microbial toxins. Edited by $\mathrm{P}$ Gopalakrishnakone, B Stiles, A Alape-Girón, JD Dubreuil, and M Mandal. Springer Netherlands, Dordrecht, the Netherlands. pp. 1-13.

Stewart CN, Adang MJ, All JN, Boerma HR, Cardineau G, Tucker D, et al. 1996. Genetic transformation, recovery, and characterization of fertile soybean transgenic for a synthetic Bacillus thuringiensis cryIAc gene. Plant Physiology, 112: 121-129. PMID:8819322. doi:10.1104/pp.112.1.121.

Storer NP, Babcock JM, Schlenz M, Meade T, Thompson GD, Bing JW, et al. 2010. Discovery and characterization of field resistance to Bt maize: Spodoptera frugiperda (Lepidoptera: Noctuidae) in Puerto Rico. Journal of Economic Entomology, 103: 1031-1038. PMID:20857709. doi:10.1603/ EC10040.

Tabashnik BE, Van Rensburg JBJ, and Carrière Y. 2009. Field-evolved insect resistance to Bt crops: definition, theory, and data. Journal of Economic Entomology, 102: 2011-2025. PMID:20069826. doi:10.1603/029.102.0601.

Tabashnik BE, Brévault T, and Carrière Y. 2013. Insect resistance to Bt crops: lessons from the first billion acres. Nature Biotechnology, 31: 510-521. PMID:23752438. doi:10.1038/nbt.2597.

Tian J-C, Collins HL, Romeis J, Naranjo SE, Hellmich RL, and Shelton AM. 2012. Using field-evolved resistance to Cry $1 \mathrm{~F}$ maize in a lepidopteran pest to demonstrate no adverse effects of Cry1F on one of its major predators. Transgenic Research, 21: 1303-1310. PMID:22373893. doi:10.1007/ s11248-012-9604-4.

Tian J-C, Wang X-P, Long L-P, Romeis J, Naranjo SE, Hellmich RL, et al. 2013. Bt crops producing Cry1Ac, Cry2Ab and Cry1F do not harm the green lacewing, Chrysoperla rufilabris. PLoS ONE, 8: e60125. PMID:23544126. doi:10.1371/journal.pone.0060125.

Van Lenteren JC, and Bueno HPV. 2003. Augmentative biological control of arthropods in Latin America. Biological Control, 48: 123-139. doi:10.1023/A:1022645210394.

Venugopal PD, Coffey PL, Dively GP, and Lamp WO. 2014. Adjacent habitat influence on stink bug (Hemiptera: Pentatomidae) densities and the associated damage at field corn and soybean edges. PLoS ONE, 9: e109917. PMID:25295593. doi:10.1371/journal.pone.0109917. 
Walker DR, All JN, McPherson RM, Boerma HR, and Parrott WA. 2000. Field evaluation of soybean engineered with a synthetic crylAc transgene for resistance to corn earworm, soybean looper, velvetbean caterpillar (Lepidoptera: Noctuidae), and lesser cornstalk borer (Lepidoptera: Pyralidae). Journal of Economic Entomology, 93: 613-622. PMID:10902306. doi:10.1603/0022-0493-93.3.613.

Wenes A-L, Bourguet D, Andow DA, Courtin C, Carré G, Lorme P, et al. 2006. Frequency and fitness cost of resistance to Bacillus thuringiensis in Chrysomela tremulae (Coleoptera: Chrysomelidae). Heredity, 97: 127-134. PMID:16705321. doi:10.1038/sj.hdy.6800845.

Xiao Y, Dai Q, Hu R, Pacheco S, Yang Y, Liang G, et al. 2017. A single point mutation resulting in cadherin mislocalization underpins resistance against Bacillus thuringiensis toxin in cotton bollworm. Journal of Biological Chemistry, 292: 2933-2943. PMID:28082675. doi:10.1074/jbc.M116.768671.

Yang F, Kerns D, and Huang F. 2015. Refuge-in-the-bag strategy for managing insect resistance to $B t$ maize. Outlooks on Pest Management, 26: 226-228. doi:10.1564/v26_oct_10.

Yu H, Li Y, Li X, Romeis J, and Wu K. 2013. Expression of CrylAc in transgenic Bt soybean lines and their efficiency in controlling lepidopteran pests. Pest Management Science, 69: 1326-1333. PMID:23564718. doi:10.1002/ps.3508.

Yu X-D, Liu Z-C, Huang S-L, Chen Z-Q, Sun Y-W, Duan P-F, et al. 2016. RNAi-mediated plant protection against aphids. Pest Management Science, 72: 1090-1098. PMID:26888776. doi:10.1002/ ps.4258.

Yuan X, Zhao M, Wei J, Zhang W, Wang B, Khaing MM, et al. 2017. New insights on the role of alkaline phosphatase 2 from Spodoptera exigua (Hübner) in the action mechanism of Bt toxin Cry2Aa. Journal of Insect Physiology, 98: 101-107. PMID:28034678. doi:10.1016/j.jinsphys.2016.12.004.

Zalucki MP, Furlong MJ, Schellhorn NA, Macfadyen S, and Davies AP. 2015. Assessing the impact of natural enemies in agroecosystems: toward "real" IPM or in quest of the Holy Grail? Insect Science, 22: 1-5. PMID:25205315. doi:10.1111/1744-7917.12172.

Zeilinger AR, Olson MD, and Andow AD. 2016. Competitive release and outbreaks of non-target pests associated with transgenic Bt cotton. Ecological Applications, 26: 1047-1054. PMID:27509747. doi:10.1890/15-1314.

Zhao JH, Ho P, and Azadi H. 2011. Benefits of $B t$ cotton counterbalanced by secondary pests? Perceptions of ecological change in China. Environmental Monitoring and Assessment, 173: 985-994. PMID:20437270. doi:10.1007/s10661-010-1439-y. 